\title{
Evaluation and comparison of drought tolerance in some wild diploid populations, tetraploid and hexaploid cultivars of wheat using stress tolerance indices
}

\author{
Sara KHOSRAVI ${ }^{1}$, Reza AZIZINEZHAD ${ }^{1,2}$, Amin BAGHIZADEH ${ }^{3}$, Mahmood MALEKI ${ }^{3}$
}

Received November 8, 2019; accepted January 4, 2020.

Delo je prispelo 8. novembra 2019, sprejeto 4. januarja 2020.

Evaluation and comparison of drought tolerance in some wild diploid populations, tetraploid and hexaploid cultivars of wheat using stress tolerance indices

Abstract: This study was carried out on grain yield in wheat genotypes with the aim of assessing genetic potential of drought tolerance. The experiment was performed as split plot in the form of randomized complete block design with three replications under normal and drought stress conditions with 32 genotypes. Based on grain yield, and under the condition of non-stress and drought stress, 5 drought tolerance indices are estimated including Tolerance Index (TOL), Stress Tolerance (STI), Mean Productivity (MP), Geometric Mean (GMP) and, Harmonic Mean (HM) for all kinds of genotypes. The analysis of yield correlation and drought tolerance indices in two environments indicated that STI, MP, GMP, HM indices were the most suitable parameters for screening wheat genotypes. Principal components analysis exhibited that the $83 \%$ of first principal component and the $15 \%$ of second one justified the variation of the initial data. Drawing bi-plot diagram declared that Sabalan, Shabrang, Aria, Azar, Azadi, and T2 genotypes were highly functional and resistant to drought stress.

Key words: wheat; index; component analysis; cluster analysis
Ovrednotenje in primerjava tolerance na sušo nekaterih divjih diploidnih populacij, tetraploidnih in heksaploidnih sort pšenice $\mathrm{z}$ uporabo indeksov tolerance na stres

Izvleček: Raziskava je bila opravljena na pridelku zrnja med genotipi pšenice za oceno genetskega potenciala tolerance na sušo. Poskus je bil izveden kot popolni naključni bločni poskus z deljenkami s tremi ponovitvami na 32 genotipih pšenice v normalnih in sušnih razmerah. Na osnovi pridelka je bilo za vse genotype v nestresnih razmerah in v razmerah sušnega stresa določenih 5 indeksov tolerance na sušo in sice: indeks tolerance (TOL), stresna toleranca (STI), srednja produktivnost (MP), geometrična sredina (GMP) in harmonična sredina (HM). Analiza korelacije med pridelkom in indeksi tolerance na sušo je pokazala, da so bili v obeh okoljih za ovrednotenje genotipov pšenice primerni STI, MP, GMP, HM indeksi. Analiza glavnih komponent je pokazala, da je $83 \%$ variabilnosti izvirnih podatkov pojasnila prva komponenta, $15 \%$ pa druga. Bi-plot diagram je pokazal, da so genotipi pšenice Sabalan, Shabrang, Aria, Azar, Azadi, in T2 zelo produktivni in odporni na sušni stress.

Ključne besede: pšenica; indeks; analiza component; klasterska analiza

1 Department of Plant Breeding and Biotechnology, Science and Research Branch, Islamic Azad University, Tehran, Iran

2 Corresponding author, e-mail: r.azizi@srbiau.ac.ir

3 Department of Biotechnology, Institute of Science and High Technology and Environmental Sciences, Graduate University of Advanced Technology, Kerman, Iran 


\section{INTRODUCTION}

Wheat (Triticum aestivum L.) is the most important crop in the world (Sleper and Poehlman, 2006) and is cultivated in more than 250 million hectares of agricultural lands of all over the world (Royo and Di Fonzo, 2005). It is estimated that about 67 percent of the total Iranian wheat is produced in arid lands (Shamsi et al., 2011). So many breeding programs have been developed to improve drought tolerance of crop (Maazou et al., 2016). The crop rotation diversity is associated with a greater yield stability under abnormal conditions like drought stress (Gaudin et al., 2015). Selection of drought-resistant cultivars is the best solution to improve stability of crop yield in dry conditions (Farshadfar et al., 2012).

Drought tolerance is a quantitative trait that is controlled by many genes (Fleury et al., 2010). Thus, detecting of drought-tolerance genotypes is very difficult (Takeda and Matsuoka, 2008). Evaluation of relative yield of genotypes under drought stress and non-stress conditions is a starting point for identification of droughttolerant mechanisms and for screening of drought-tolerant genotypes (Fernandez, 1992; Mitra, 2001). Based on tolerance index (TOL) as difference in the yield of two genotypes under both normal and stress conditions, the higher TOL indicates more sensitivity of plants to stress and thus, the selection was mainly based on the low amounts of TOL, but high mean productivity (MP), the mean yield of each genotype in two conditions, shows more tolerance to stress (Rosielle and Hamblin, 1981). In 1992, on the base of yield, mung bean's genotypes were divided into four groups under both normal and stress environments: (A) high-yield under both conditions; (B) high-yield under normal conditions; (C) good-yield under drought stress and (D) low-yield under both normal and drought stress condition (Fernandez, 1992). It showed that selections based on TOL and MP would be able to separate genotypes of B and D groups. By MP index, high yielding genotypes under both normal and stress conditions could be selected but this index is not able to distinguish between $\mathrm{A}$ and $\mathrm{B}$ groups. The MP index also leads to choose high yielding genotypes but with a low stress tolerance (Fernandez, 1992; Rosielle and Hamblin, 1981). When there is a significant relative difference between the yield under stress and non-stress conditions, MP index is oriented toward the yield under normal conditions so to obviate this problem, geometric mean productivity (GMP) index that is based on the geometric mean of genotypes yield under normal and stress conditions was proposed by Fernandez (1992). Since this index is less sensitive to different values in normal conditions and drought stress, Fernandez introduced another index called stress tolerance index (STI), in order to identify high-yield genotypes under two normal and stress conditions and also for identifying drought tolerance genotypes. This index considers the stress intensity (SI) that is estimated as mean ratio of genotypes yield in the stress environment to the normal environment from one (Fischer and Maurer, 1978; Schneider et al., 1997). High values of GMP and STI are subjected to determine stress tolerance genotypes. Harmonic mean index (HM) was also introduced by Fernandez. These indices are introduced as the best having a high correlation with grain yield in both normal and stress environments (Fernandez, 1992).

In 2006, STI, GMP, and MP indices were evaluated for selecting of wheat genotypes under water deficit conditions (Golabadi et al., 2006; Mardeh et al., 2006). Also, in 2009, STI, GMP, and MP were introduced as the most effective indicators for evaluating and selecting wheat genotypes under drought stress (Talebi et al., 2009).

The purpose of the present study is to determine the genotypes with yield stability under drought stress and non-stress conditions as well as introducing the appropriate indices for screening wheat genotypes under stress and non-stress conditions.

\section{MATERIALS AND METHODS}

In this experiment, 7 population of wild diploid wheat (Triticum boeoticum Boiss.) with AA genome, 5 population of wild diploid wheat (Aegilops tauschii Coss.) with DD genome, 10 cultivars of tetraploid wheat (Triticum durum Desf.) with AABB genome and $10 \mathrm{cul}$ tivars of hexaploid wheat (Triticum aestivum L.) with AABBDD genome, (Table 1) have been used. Wheat seeds were implanted in research farm of Graduate University of Advanced Technology in Kerman province in October 2016. The experiment was designed as split plot in a randomized complete block design (RCBD), with three replications, assigning normal and stress levels as main plots and population and wheat cultivars as sub-plots. Each plot consisted of three lines keeping $2 \mathrm{~m}$ length and $20 \mathrm{~cm}$ distance within which on each line 15 seeds had been implanted. All plots of the normal and stress experiments were well watered (once every 7 days) by using an installed pipeline system. The volume of water input for each plot was controlled by using adjustable counter. Since April (the grain-filling period), drought stress treatment, irrigation at 30-day intervals, was imposed on the plants until the beginning of June (time of harvesting). After harvesting each plot at crop maturity, grain yield was recorded in both normal and stress conditions.

Tolerance index, stress tolerance index, mean pro- 
Table 1: Names of genotypes used in the study

\begin{tabular}{|c|c|c|c|c|}
\hline Genotype & Species & Genome & Ploidy level & Source \\
\hline B1 & Triticum. boeticum & $\begin{array}{l}\text { Wild Diploid Genome } \\
\text { AA }\end{array}$ & $2 \mathrm{n}=2 \mathrm{x}=14$ & Lorestan-10 km to Nurabad-On behalf of Alshatr \\
\hline B2 & Triticum. boeticum & $\begin{array}{l}\text { Wild Diploid Genome } \\
\text { AA }\end{array}$ & $2 \mathrm{n}=2 \mathrm{x}=14$ & Lorestan - Firouzabad-Khorramabad Road \\
\hline B3 & Triticum. boeticum & $\begin{array}{l}\text { Wild Diploid Genome } \\
\text { AA }\end{array}$ & $2 \mathrm{n}=2 \mathrm{x}=14$ & $\begin{array}{l}\text { Kermanshah - Deh sefeed-Not-To-Dumbel Is- } \\
\text { lamabad Kermanshah }\end{array}$ \\
\hline B4 & Triticum. boeticum & $\begin{array}{l}\text { Wild Diploid Genome } \\
\text { AA }\end{array}$ & $2 \mathrm{n}=2 \mathrm{x}=14$ & Kermanshah - $20 \mathrm{~km}$ from Paveh to Ravensar \\
\hline B6 & Triticum. boeticum & $\begin{array}{l}\text { Wild Diploid Genome } \\
\text { AA }\end{array}$ & $2 \mathrm{n}=2 \mathrm{x}=14$ & Kurdistan - Two Sanandaj Moths \\
\hline B7 & Triticum. boeticum & $\begin{array}{l}\text { Wild Diploid Genome } \\
\text { AA }\end{array}$ & $2 \mathrm{n}=2 \mathrm{x}=14$ & Kurdistan - $10 \mathrm{~km}$ after Ganji to Ghorveh \\
\hline B8 & Triticum. boeticum & $\begin{array}{l}\text { Wild Diploid Genome } \\
\text { AA }\end{array}$ & $2 \mathrm{n}=2 \mathrm{x}=14$ & Kurdistan - Bolban abad city \\
\hline $\mathrm{T} 1$ & Aegilops tauschii & $\begin{array}{l}\text { Wild Diploid Genome } \\
\text { DD }\end{array}$ & $2 \mathrm{n}=2 \mathrm{x}=14$ & Gilan - Isfahan-Rasht Road \\
\hline $\mathrm{T} 2$ & Aegilops tauschii & $\begin{array}{l}\text { Wild Diploid Genome } \\
\text { DD }\end{array}$ & $2 \mathrm{n}=2 \mathrm{x}=14$ & Mazandaran-Amol \\
\hline $\mathrm{T} 3$ & Aegilops tauschii & $\begin{array}{l}\text { Wild Diploid Genome } \\
\text { DD }\end{array}$ & $2 \mathrm{n}=2 \mathrm{x}=14$ & Karaj Road - Chalous (50 km before Chalous) \\
\hline $\mathrm{T} 4$ & Aegilops tauschii & $\begin{array}{l}\text { Wild Diploid Genome } \\
\text { DD }\end{array}$ & $2 \mathrm{n}=2 \mathrm{x}=14$ & Ardebil-Moghan-Parsabad plain \\
\hline T5 & Aegilops tauschii & $\begin{array}{l}\text { Wild Diploid Genome } \\
\text { DD }\end{array}$ & $2 \mathrm{n}=2 \mathrm{x}=14$ & East Azarbaijan - $10 \mathrm{~km}$ from Ahar-Kalibar road \\
\hline Aria & Triticum durum & Tetraploid AABB & $2 \mathrm{n}=4 \mathrm{x}=28$ & \\
\hline Behrang & Triticum durum & Tetraploid AABB & $2 \mathrm{n}=4 \mathrm{x}=28$ & \\
\hline Dehdasht & Triticum durum & Tetraploid AABB & $2 n=4 x=28$ & \\
\hline Dena & Triticum durum & Tetraploid AABB & $2 \mathrm{n}=4 \mathrm{x}=28$ & \\
\hline Shabrang & Triticum durum & Tetraploid AABB & $2 \mathrm{n}=4 \mathrm{x}=28$ & \\
\hline Karkhe & Triticum durum & Tetraploid AABB & $2 n=4 x=28$ & \\
\hline Yavarus & Triticum durum & Tetraploid AABB & $2 \mathrm{n}=4 \mathrm{x}=28$ & \\
\hline $\mathrm{DW} / 95 / 4$ & Triticum durum & Tetraploid AABB & $2 n=4 x=28$ & \\
\hline $\mathrm{DW} / 90 / 8$ & Triticum durum & Tetraploid AABB & $2 \mathrm{n}=4 \mathrm{x}=28$ & \\
\hline WS & Triticum durum & Tetraploid AABB & $2 \mathrm{n}=4 \mathrm{x}=28$ & \\
\hline Azar & Triticum durum & Hexaploid AABBDD & $2 n=6 x=42$ & \\
\hline Azadi & Triticum durum & Hexaploid AABBDD & $2 n=6 x=42$ & \\
\hline Pishtaz & Triticum durum & Hexaploid AABBDD & $2 n=6 x=42$ & \\
\hline Roshan & Triticum durum & Hexaploid AABBDD & $2 n=6 x=42$ & \\
\hline Sabalan & Triticum durum & Hexaploid AABBDD & $2 n=6 x=42$ & \\
\hline Superhead & Triticum durum & Hexaploid AABBDD & $2 n=6 x=42$ & \\
\hline Shiraz & Triticum durum & Hexaploid AABBDD & $2 n=6 x=42$ & \\
\hline Hirmand & Triticum durum & Hexaploid AABBDD & $2 n=6 x=42$ & \\
\hline Moghan & Triticum durum & Hexaploid AABBDD & $2 n=6 x=42$ & \\
\hline mr-17 & Triticum durum & Hexaploid AABBDD & $2 \mathrm{n}=6 \mathrm{x}=42$ & \\
\hline
\end{tabular}


S. KHOSRAVI et al.

Table 2: Formulas drought tolerance indices

\begin{tabular}{lll}
\hline Index & Formula & Source \\
\hline Tolerance Index (TOL) & $\mathrm{Y}_{\mathrm{p}}-\mathrm{Y}_{\mathrm{s}}$ & (Rosielle and Hamblin, 1981) \\
Stress Tolerance Index (STI) & $\left(\mathrm{Y}_{\mathrm{p}}^{*} \mathrm{Y}_{\mathrm{s}}\right) /\left(\overline{\mathrm{y}}_{\mathrm{P}}\right)^{2}$ & (Fernandez, 1992) \\
Mean productivity (MP) & $(\mathrm{Yp}+\mathrm{Ys}) / 2$ & (Rosielle and Hamblin, 1981) \\
Geometric Mean Productivity (GMP) & $\left(\mathrm{Y}_{\mathrm{P}}^{*} \mathrm{Y}_{\mathrm{s}}\right)^{1 / 2}$ & (Fernandez, 1992) \\
Harmonic Mean (HM) & {$[2(\mathrm{Yp} \times \mathrm{Ys}) /(\mathrm{Yp}+\mathrm{Ys})]$} & (Fernandez, 1992) \\
\hline
\end{tabular}

ductivity (Rosielle and Hamblin, 1981) and the geometric mean productivity and harmonic mean (Fernandez, 1992) were calculated according to the following formulas (Table 2):

In which, YP and YS are the yield of each genotype under non-stress and stress conditions, respectively, and $\overline{\mathrm{y}} \mathrm{P}$ is the mean yield of all genotypes.

After calculating of different indices, correlation between grain yield under normal and stress conditions (YP, YS) and stress tolerance indices was calculated and the best index was determined. So that, the indices having high and significant correlation with grain yield under both conditions were introduced as the best indicators. Also, principal component analysis of the indices was performed for further evaluation of drought tolerant cultivars. To identify relatively tolerant cultivars, a biplot chart was drawn according to the relationship of the studied components and indices. Finally drought tolerant cultivars were identified for the weather condition of this experiment.

In order to obtain data analysis, SPSS ver. 24 and Excel 2017 software were used. Also, yield stability analysis was done using biplot software. In order to do this, each one of the drought stress treatment levels were considered as an environment and the mean yield (per unit surface) of the studied cultivars at different levels of the less-watering stress was analyzed for stability.

\section{RESULTS AND DISCUSSION}

For all genotypes, five indices of drought tolerance, yield potential (YP), and stress yield (YS) were calculated (Table 3). According to many of the researches these indices are the most applicant ones for selecting drought-tolerance genotypes (Mardeh et al., 2006; Pirayvatlou, 2001; Talebi et al., 2009). There was a significant difference among stress conditions for grain yield. The grain yield mean under normal and stress conditions was $2.36 \mathrm{~g} \mathrm{~m}^{-2}$ and $1.10 \mathrm{~g} \mathrm{~m}^{-2}$, respectively. The stress intensity index (SI) would get value between 0 and 1 . The larger value of stress intensity indicates more severe stress conditions (Raman et al., 2012), in this study SI was equal to 0/54, that showed yield reduction was about more than onehalf under stress conditions in comparison to yield under normal conditions. Indices, that have strong correlation with the grain yield under normal and stress condition, are suitable for selecting stress tolerance genotypes (Farshadfar et al., 2012).

The T5 wild diploid and Sabalan hexaploid genotypes possessed the highest value for grain yield under normal and stress conditions, respectively. The genotypes of B2 and B8 in normal condition and Moghan and B7 in stress condition had the least value for grain yield (Table 3 ). The highest difference in yield (YS-YP) was found in the population $\mathrm{T} 1, \mathrm{~T} 3, \mathrm{~T} 4, \mathrm{~T} 5$, and superhead.

Correlation coefficients between drought tolerance indices and seed yield in normal and stress conditions presented in Table 4 . There was a significant positive correlation between YP and YS $(r=0.67, p<0.01)$ showing that high yield under normal condition resulted in relatively high yield under stress conditions. Also, YP and YS with STI $(\mathrm{r}=0.85$ and 0.90$), \mathrm{MP}(\mathrm{r}=0.95$ and $0.86)$, GMP ( $r=0.89$ and 0.92$)$, and HM (0.83 and 0.95) have significant positive correlation $(p<0.01)$ (Table 4$)$. These suggest that in selecting high yielding lines under stress and non-stress conditions, theses indices are very important. In fact, high correlation YS and YP with other indices is critical for selecting tolerance genotypes (Farshadfar et al., 2012). There is a significant positive correlation between YP and TOL $(r=0.82, p<0.01)$ but for YS and TOL, this correlation is negative $(r=0.14)$ (Table 4). It has been concluded that selecting based on TOL, results in reduced yield in normal condition. Khalili et al. (2012) reported that MP, GMP and STI indices had a positive and significant correlation with grain yield under normal and stress conditions. Also, Naghavi (2013) indicated that there was a positive correlation between MP, GMP, YS and YP. Drought resistance indices such as MP and GMP could be appropriate for identifying tolerant genotypes (Farshadfar et al., 2012; Khalili et al., 2014; Mardeh et al., 2006; Mirzaei et al., 2014; Naghavi et al., 2013).

Principal component analysis (PCA) are represented in Table 5. Principal component analysis (PCA) showed that $83.77 \%$ of variations resulted from YP, YS, 
Table 3: Yield potential (YP), stress yield (YS), and five indices of drought tolerance for 32 wheat genotypes

\begin{tabular}{|c|c|c|c|c|c|c|c|}
\hline Genotype & YP & YS & TOL & STI & $\mathrm{MP}$ & GMP & HM \\
\hline $\mathrm{B} 1$ & 0.2 & 0.11 & 0.08 & 0 & 0.15 & 0.15 & 0.14 \\
\hline B2 & 0.18 & 0.15 & 0.03 & 0 & 0.16 & 0.16 & 0.16 \\
\hline B3 & 0.30 & 0.17 & 0.13 & 0.01 & 0.24 & 0.23 & 0.22 \\
\hline $\mathrm{B} 4$ & 0.44 & 0.17 & 0.26 & 0.01 & 0.30 & 0.27 & 0.25 \\
\hline B6 & 0.67 & 0.11 & 0.56 & 0.01 & 0.39 & 0.27 & 0.19 \\
\hline B7 & 0.20 & 0.1 & 0.1 & 0 & 0.15 & 0.14 & 0.13 \\
\hline B8 & 0.16 & 0.13 & 0.03 & 0 & 0.15 & 0.14 & 0.14 \\
\hline $\mathrm{T} 1$ & 4.6 & 1.4 & 3.20 & 1.25 & 3.03 & 2.57 & 2.18 \\
\hline $\mathrm{T} 2$ & 2.50 & 2.93 & -0.4 & 1.39 & 2.71 & 2.70 & 2.70 \\
\hline $\mathrm{T} 3$ & 4.16 & 1.78 & 2.37 & 1.40 & 2.97 & 2.72 & 2.50 \\
\hline $\mathrm{T} 4$ & 5.14 & 1.81 & 3.23 & 1.76 & 3.47 & 3.05 & 2.68 \\
\hline $\mathrm{T} 5$ & 5.40 & 2.28 & 3.12 & 2.34 & 3.84 & 3.51 & 3.21 \\
\hline Dehdasht & 2.15 & 0.55 & 1.6 & 0.22 & 1.35 & 1.08 & 0.87 \\
\hline Dena & 1.97 & 0.43 & 1.54 & 0.16 & 1.20 & 0.92 & 0.70 \\
\hline DW/90/8 & 1.50 & 1.90 & -0.3 & 0.54 & 1.70 & 1.69 & 1.68 \\
\hline DW/95/4 & 1.87 & 0.43 & 1.44 & 0.15 & 1.15 & 0.89 & 0.69 \\
\hline Karkhe & 2.14 & 0.96 & 1.17 & 0.39 & 1.55 & 1.43 & 1.33 \\
\hline Yavarus & 1.9 & 1.12 & 0.78 & 0.40 & 1.51 & 1.46 & 1.41 \\
\hline Shabrang & 2.77 & 1.98 & 0.79 & 1.04 & 2.38 & 2.34 & 2.31 \\
\hline Behrang & 3.17 & 0.23 & 2.94 & 0.13 & 1.70 & 0.85 & 0.42 \\
\hline WS & 0.72 & 0.56 & 0.15 & 0.07 & 0.64 & 0.63 & 0.63 \\
\hline Aria & 3.1 & 2.05 & 1.05 & 1.20 & 2.57 & 2.52 & 2.46 \\
\hline Azadi & 3.09 & 1.53 & 1.56 & 0.89 & 2.31 & 2.17 & 2.04 \\
\hline Azar & 3.58 & 1.90 & 1.68 & 1.29 & 2.74 & 2.61 & 2.48 \\
\hline Hirmand & 3.98 & 1.68 & 2.30 & 1.26 & 2.83 & 2.58 & 2.36 \\
\hline Moghan & 1.72 & 0.1 & 1.62 & 0.03 & 0.91 & 0.41 & 0.18 \\
\hline $\mathrm{mr}-17$ & 1.14 & 1.16 & -0.02 & 0.25 & 1.15 & 1.14 & 1.14 \\
\hline Pishtaz & 2.60 & 0.53 & 2.07 & 0.26 & 1.57 & 1.17 & 0.88 \\
\hline Roshan & 3.11 & 1.24 & 1.87 & 0.73 & 2.17 & 1.96 & $1 / 77$ \\
\hline Sabalan & 3.55 & 3.30 & 0.24 & 2.22 & 3.43 & 3.42 & 3.42 \\
\hline Shiraz & 2.68 & 0.97 & 1.70 & 0.49 & 1.82 & 1.61 & 1.43 \\
\hline Superhead & 4.75 & 1.42 & 3.33 & 1.27 & 3.08 & 2.59 & 2.18 \\
\hline
\end{tabular}

STI, MP, GMP, and HM as first PCA (Table 5). Therefore, PCA 1, the first dimension, was named as a yield component and drought tolerance.

The second principal component analysis (PCA) indicated $15.20 \%$ of total variations. The highest positive factor in the second PCA was YP and TOL, and the highest negative factor was YS. Therefore, this component can be named as sensitivity component to stress. The genotypes with low values of the second PCA have the least sensitivity to stress conditions. Thus, for both non-stress and stress environment, selection of genotypes with high PCA1 and low PCA2 are recommended. Therefore, genotypes B1 and B8 have high PCA1 and low PCA2 that are preferable genotypes. It's been also reported that genotypes with larger PCA1 and lower PCA2 scores gave high yields (stable genotypes), and genotypes with lower PCA1 and larger PCA2 scores had low yields (unstable genotypes) (Kaya et al., 2002). The principal component analysis (PCA) also was described by many of researchers (Parchin et al., 2013; Zabet et al., 2003). Shafazadeh 
Table 4: Correlation coefficients between drought tolerance indices and seed yield in normal and stress conditions

\begin{tabular}{|c|c|c|c|c|c|c|c|}
\hline & YP & YS & TOL & STI & $\mathrm{MP}$ & GMP & $\mathrm{HM}$ \\
\hline YP & 1 & & & & & & \\
\hline YS & $0.67^{\star *}$ & 1 & & & & & \\
\hline TOL & $0.82^{\star \star}$ & 0.14 & 1 & & & & \\
\hline STI & $0.85^{\star *}$ & $0.90^{\star *}$ & $0.45^{\star *}$ & 1 & & & \\
\hline MP & $0.95^{\star \star}$ & $0.86^{* *}$ & $0.62^{\star \star}$ & $0.94^{\star *}$ & 1 & & \\
\hline GMP & $0.89^{\star *}$ & $0.92^{\star *}$ & $0.94^{* *}$ & $0.96^{\star *}$ & $0.98^{\star *}$ & 1 & \\
\hline $\mathrm{HM}$ & $0.83^{* *}$ & $0.95^{\star *}$ & $0.39^{\star}$ & $0.96^{* *}$ & $0.95^{\star *}$ & $0.99^{* *}$ & 1 \\
\hline
\end{tabular}

${ }^{*} p<0.05,{ }^{* *} p<0.01$.

Table 5: Linear composition coefficients of the main components of stress tolerance indexes

\begin{tabular}{llllllllll}
\hline Component & Eigen values & Variance & \multicolumn{2}{l}{ Study Indicators } & & & & \\
\hline & & & YP & YS & TOL & STI & MP & GMP & HM \\
1 & 5.8 & 83.77 & 0.93 & 0.88 & 0.58 & 0.96 & 0.99 & 0.99 & 0.97 \\
2 & 1.06 & 15.20 & 0.34 & -0.45 & 0.81 & -0.13 & 0.05 & -0.10 & -0.21 \\
\hline
\end{tabular}

et al. (2004) in investigation of response of bread wheat genotypes to drought stress conditions, concluded that MP, GMP and STI indices in specification of drought tolerant genotypes provide an agreeable result than TOL and SSI indices.

For comparison among genotypes, many researchers have used of biplot analysis (Nazari and Pakniyat, 2010). Biplot analysis was used to study the relationship between drought tolerance indices and grain yield under both normal and drought stress conditions (Figure 1). This diagram can be divided into four zones. Zone A includes the best genotypes such as Sabalan, T2, Aria, Azar and Azadi which have high-yield and are resistant to stress. Zone B includes T1, T3, T4, T5, Hirmanad, Shiraz, Superhead and Roshan which have a high-yield but are sensitive to stress. Zone $\mathrm{C}$ does not possess desirable properties, since has low-yield and are sensitive to stress. Most of the genotypes of this group were wild diploids. The genotypes of zone $\mathrm{D}$, unlike the low-yield, are resistant to drought stress. For soybean, applying genotypetrait (GT) biplot to the multiple trait data illustrated that, GT biplots graphically displayed the interrelationships among seed yield, oil content, protein content, plant height and days to maturity and facilitated visual cultivar comparisons and selection (Yan and Rajcan, 2002). Mollasadeghi et al. (2011) reported 4 zone with 12 wheat genotypes.

The cluster analyses based on yield under normal and stress conditions, and the 5 mentioned indices were carried out, and the results are shown in Figure 2. UPG-

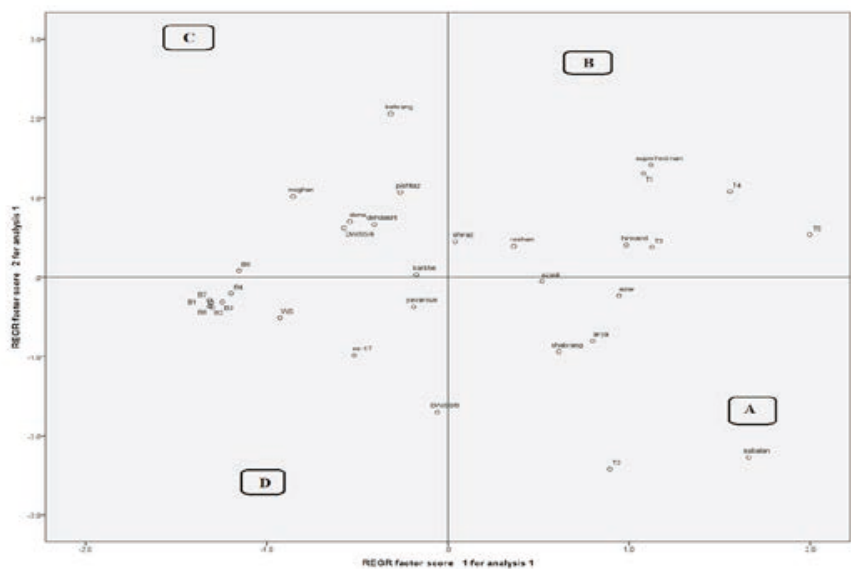

Figure 1: Biplot for drought tolerance indices in 32 genotypes wheat based on first two components. 


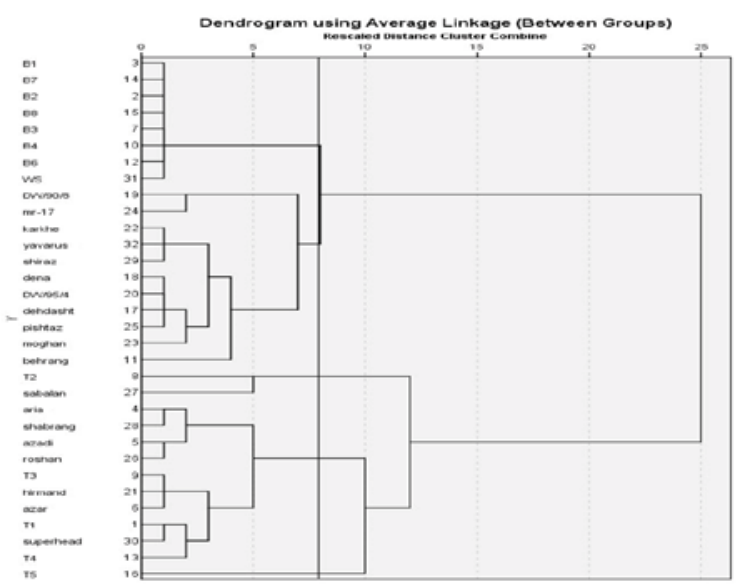

Figure 2: Dendrogram of cluster analysis of the wheat population tested based on TOL, STI, MP, GMP, HM indices using UPGMA method

MA dendrogram clustered the examined 32 wheat genotypes into two five clusters (Figure 2). Genotypes B1, B7, B2, B8, B3, B4, B6 and WS, which have the low yield and are resistant to drought stress, were put together. Second group are DW/90/8, mr-17, Karkheh, Yavarus, Shiraz, Dena, DW/95/4, Dehdasht, Pishtaz, Moghan, Behrang which have low yield. 'T2' and 'Sabalan' formed the third group with the highest yield, in normal and resistant to stress especially in stress conditions. Fourth group contains of genotypes are Aria, Shabrang, Azadi, Roshan, T3, Hirmand, Azar, T1, Superhead and T4, which are high in terms of yield and can be significant. 'T5' forms the $5^{\text {th }}$ group and this genotype is high-yield and sensitive to stress.

The results of cluster analysis completely agreed by those of principal component analysis and biplot analysis. Based on biplot analysis, genetic variations were observed in studied genotype under drought stress. This is also approved by cluster analysis. Other researchers, using cluster analysis based on stress tolerance indices and genotypic classification, indicated that the results obtained from this method are consistent with the principal components analysis (Ahmadizadeh et al., 2012; Mohammadi et al., 2011; Rad and Abbasian, 2011). The clusteranalysis of 30 genotypes of wheat were placed into three separate groups (Parchin et al., 2013).

For tolerate adverse environmental conditions, there are different mechanisms. Sometimes, a combination of these mechanisms causes yield stability in stress conditions. The selection of genotype with such characteristics is not a simple task and is mainly difficult in the early stages of plant breeding. Thus, identifying and introducing new crop genotypes being resistant to waterlimited conditions is one of the best methods for reducing the effects of drought stress. This method along with farm management are very effective strategies to reduce the negative effects of drought stress.

\section{CONCLUSION}

In the studied population, STI, MP, GMP and HM indices can be used to identify drought tolerant genotypes. Based on biplot chart, Sabalan, T2, Aria, Azar, Azadi genotypes retained both drought tolerance and high yield.

\section{REFERENCES}

Ahmadizadeh, M., Valizadeh, M., Shahbazi, H., Nori, A. (2012). Behavior of durum wheat genotypes under normal irrigation and drought stress conditions in the greenhouse. African Journal of Biotechnology, 11, 1912-1923. https://doi. org/10.5897/AJB11.2370

Farshadfar, E., Pour Siahbidi, M.M., Abooghadareh, A.P. (2012). Repeatability of drought tolerance indices in bread wheat genotypes. International Journal of Agriculture and Crop Sciences, 4, 891-903.

Fernandez, G.C. (1992). Effective selection criteria for assessing plant stress tolerance, in: Proceeding of the International Symposium on Adaptation of Vegetables and Other Food Crops in Temperature and Water Stress, Aug. 13-16, Shanhua, Taiwan, pp. 257-270.

Fischer, R.A., Maurer, R. (1978). Drought resistance in spring wheat cultivars. I. Grain yield responses. Australian Journal of Agricultural Research, 29, 897-912. https://doi. org/10.1071/AR9780897

Fleury, D., Jefferies, S., Kuchel, H., Langridge, P. (2010). Genetic and genomic tools to improve drought tolerance in wheat. Journal of Experimental Botany, 61, 3211-3222. https://doi. org/10.1093/jxb/erq152 
Gaudin, A.C., Tolhurst, T.N., Ker, A.P., Janovicek, K., Tortora, C., Martin, R.C., Deen, W. (2015). Increasing crop diversity mitigates weather variations and improves yield stability. PloS one, 10, e0113261. https://doi.org/10.1371/journal. pone.0113261

Golabadi, M., Arzani, A., Maibody, S.M. (2006). Assessment of drought tolerance in segregating populations in durum wheat. African Journal of Agricultural Research, 1, 162-171.

Kaya, Y., Palta, C., Taner, S. (2002). Additive main effects and multiplicative interactions analysis of yield performances in bread wheat genotypes across environments. Turkish Journal of Agriculture and Forestry, 26, 275-279.

Khalili, M., Alireza, P.-A., Naghavi, M.R., Mohammad-Amini, E. (2014). Evaluation of drought tolerance in safflower genotypes based on drought tolerance indices. Notulae Botanicae Horti Agrobotanici Cluj-Napoca, 42, 214-218. https:// doi.org/10.15835/nbha4219331

Khalili, M., Naghavi, M.R., Aboughadareh, A.P., Talebzadeh, S.J. (2012). Evaluating of drought stress tolerance based on selection indices in spring canola cultivars (Brassica napus L.). Journal of Agricultural Science, 4, 78. https://doi. org/10.5539/jas.v4n11p78

Maazou, A.-R.S., Tu, J., Qiu, J., Liu, Z. (2016). Breeding for drought tolerance in maize (Zea mays L.). American Journal of Plant Sciences, 7, 1858. https://doi.org/10.4236/ ajps.2016.714172

Mardeh, A.S. S., Ahmadi, A., Poustini, K., Mohammadi, V. (2006). Evaluation of drought resistance indices under various environmental conditions. Field Crops Research, 98, 222-229. https://doi.org/10.1016/j.fcr.2006.02.001

Mirzaei, S., Farshadfar, E., Mirzaei, Z. (2014). Evaluation of physiologic and metabolic indicators of drought resistance in chickpea. International Journal of Biosciences, 5, 106113. https://doi.org/10.12692/ijb/5.2.106-113

Mitra, J. (2001). Genetics and genetic improvement of drought resistance in crop plants. Current Science, 758-763.

Mohammadi, M., Karimizadeh, R., Abdipour, M. (2011). Evaluation of drought tolerance in bread wheat genotypes under dryland and supplemental irrigation conditions. Australian Journal of Crop Science, 5, 487.

Mollasadeghi, V., Valizadeh, M., Shahryari, R., Imani, A.A. (2011). Evaluation of end drought tolerance of 12 wheat genotypes by stress indices. World Applied Sciences Journal, 13, 545-551.

Naghavi, M.R., ABOUGHADAREH, A.P., KHALILI, M. (2013). Evaluation of drought tolerance indices for screening some of corn (Zea mays L.) cultivars under environmental conditions. Notulae Scientia Biologicae, 5, 388-393. https://doi. org/10.15835/nsb539049

Nazari, L., Pakniyat, H. (2010). Assessment of drought tolerance in barley genotypes. Journal of Applied Sciences, 10, 151-156. https://doi.org/10.3923/jas.2010.151.156

Parchin, R.A., Najaphy, A., Farshadfar, E., Hokmalipour, S. (2013). Assessment of drought tolerance in genotypes of wheat by multivariate analysis. World Applied Sciences Journal, 22, 594-600.

Pirayvatlou, A.S. (2001). Relations among Yield Potential, Drought Tolerance and Stability of Yield in Bread Wheat Varieties under Water Deficit Conditions, in: Proceedings of the 10th Australian Agronomy Conference, Jan.

Rad, A.H.S., Abbasian, A. (2011). Evaluation of drought tolerance in rapeseed genotypes under non stress and drought stress conditions. Notulae Botanicae Horti Agrobotanici Cluj-Napoca, 39, 164-171. https://doi.org/10.15835/ nbha3926172

Raman, A., Verulkar, S., Mandal, N., Variar, M., Shukla, V., Dwivedi, J., Singh, B., Singh, O., Swain, P., Mall, A. (2012). Drought yield index to select high yielding rice lines under different drought stress severities. Rice, 5, 31. https://doi. org/10.1186/1939-8433-5-31

Rosielle, A.A., Hamblin, J. (1981). Theoretical aspects of selection for yield in stress and non-stress environment 1. Crop science, 21, 943-946. https://doi.org/10.2135/cropsci1981.0 011183X002100060033x

Royo, C., Di Fonzo, N. (2005). Durum Wheat Breeding: Current Approaches and Future Strategies, Volumes 1 and 2. CRC Press. https://doi.org/10.2135/cropsci1997.0011183X0037 $00010007 \mathrm{x}$

Schneider, K.A., Rosales-Serna, R., Ibarra-Perez, F., CazaresEnriquez, B., Acosta-Gallegos, J.A., Ramirez-Vallejo, P., Wassimi, N., Kelly, J.D. (1997). Improving common bean performance under drought stress. Crop Science, 37, 43-50.

Shafazadeh, M.K., YAZDAN, S.A., Amini, A., Ghanadha, M.R. (2004). Study of terminal drought tolerance in promising winter and facultative wheat genotypes using stress susceptibility and tolerance indices.

Shamsi, K., Kobraee, S., Rasekhi, B. (2011). Variation of field components and some morphological traits in bread wheat grown under drought stress. Annals of Biological Research, 2, 372-377.

Sleper, D.A., Poehlman, J.M. (2006). Breeding field crops. Blackwell publishing.

Takeda, S., Matsuoka, M. (2008). Genetic approaches to crop improvement: responding to environmental and population changes. Nature Reviews Genetics, 9, 444. https://doi. org/10.1038/nrg2342

Talebi, R., Fayaz, F., Naji, A.M. (2009). Effective selection criteria for assessing drought stress tolerance in durum wheat (Triticum durum Desf.). General and applied plant physiology, 35, 64-74.

Yan, W., Rajcan, I. (2002). Biplot analysis of test sites and trait relations of soybean in Ontario. Crop Science, 42, 11-20. https://doi.org/10.2135/cropsci2002.1100

Zabet, M., Hosein Zade, A.H., Ahmadi, A. and Khialparast, F. (2003). Effect of water stress on different traits and determination of the best water stress index in mung bean (Vigna radiata). Iranian Journal Agriculture Science, 34(4), 889-898. 